\title{
Common Transit Procedure and NCTS Implementation: the Case of Ukraine
}

\section{Roman Kril*}

Kril, R. (2021). Common Transit Procedure and NCTS Implementation: the Case of Ukraine. Lex Portus, 7(3), 32-59. https://doi.org/10.26886/2524-101X.7.3.2021.2 * Faculty of Law and Administration, Jagiellonian University (Golebia 24, 31-007 Krakow, Poland) https://orcid.org/0000-0002-3531-3934

\section{c) (2) This work is licensed under a Creative Commons Attribution- NonCommercialShareAlike 4.0 International License}

\section{ABSTRACT}

The article analyses the EU policies towards the extension of a Common Transit Procedure and the New Computerised Transit System (NCTS) over associated countries given a case of Ukraine. A reasonable amount of the EU actions and aid on implementing the NCTS are performed within frameworks of the Eastern Neighbourhood Policy. It is instrumental for approximation of customs legislation, capacity budling, and modernization of customs authorities of the EU neighboring states. However, the impact of the NCTS implementation goes far beyond mere transit arrangements. It has the potential to introduce basic principles of the EU administrative law and best practices of administration into the day-by-day performance of national customs authorities. Ukrainian customs have favorable start conditions; so far, the national customs authorities and traders have experience in utilizing customs IT solutions. However, the transition to the new transit procedure 
may face specific issues due to disproportionately strict authorization criteria for transit simplification set by national legislation that exceeds the relevant rules of the EU legislation. Such restrictions cause low popularity of the new procedures harmonized with the EU legislation. Besides, in some cases, the approximation to the EU customs legislation results in discontinuing the existing simplification of customs procedures, which raises the question of possible distortions in the implementation of respective obligations and failure to share basic principles of good administration promoted by the EU.

The key words: Common Transit Procedure, NCTS, Transit Simplifications, Association Agreement, Europeanization, good governance, customs, European Union, Ukraine.

\section{Introduction}

Simplification and streamlining transit procedures are among the core issues of facilitating international trade, addressed by many international instruments, including the WTO Trade Facilitation Agreement and WCO Kyoto Convention on Harmonization and Simplification of Customs Procedures. Furthermore, WCO recommends that national governments conclude or accede to regional agreements providing a framework for cooperation on transit. Such agreements in the WCO view should include provisions on information exchange, guarantee mechanisms, harmonized legal and security requirements, fees and charges, joint controls, coordinated border management, mutual recognition of Customs seals (Transit Guidelines. Route for efficient transit regime).

Complicity of transit procedures, which demands additional arrangements from traders and causes delays in transit of goods typically resulted in enhancing trade and customs compliance costs. Such costs are basically allocated towards three categories: the initial set-up and authorization costs; transaction-type costs (for example, preparing and submitting trade documents); the costs associated with physically presenting and inspecting goods (Grainger, 2014, p. 472). In addition, such complicities negatively affect general volumes of international trade. Due to the World Bank estimations each day of 
delay in customs causes a loss of $1 \%$ in trade between countries (Popa et al., 2015, p. 1100).

For the European countries, the most advanced transit arrangement is the 1987 Convention on a Common Transit Procedure, which forms a "common transit area" comprised of the customs territory of the EU and territories of other contracting parties to this Convention (The Union Transit Procedure (including TIR) and the Customs Status of Goods). Due to the best customs practices, that common transit area is supported by the electronic customs environment based on the EU developed IT solutions, including as the Import Control System (first phase of the Automatically Import System), Export Control System, the New Computerized Transit System, the registration, and identification number of economic operators (Economic Operator Identification and Registration, EORI) and the status of Authorized Economic Operator (AEO) (Popa et al., 2015, p. 1100). Implementing the transit arrangements and solutions, as mentioned above, is vital for any of the EU neighboring countries, which is a mutual interest for actors. For example, more than 14,000 Ukrainian companies exporting goods to EU markets would benefit from general simplifications and reduction of costs of moving goods across the border thanks to joining the Common Transit System (Butin \& Shulga, 2019).

\section{Methodology}

The paper explores the legal framework and policy documents concerning the extension of a Common Transit Procedure and implementation of the NCTS by the EU neighbor countries. The research utilizes the view on said processes as a part of the EU external policy towards promoting trade facilitation and extension of basic principles of good governance and administrative law. A part of the present research comprises empirical data on arrangements, which Ukrainian authorities made in fulfilling obligations on accession to the Convention on a Common Transit Procedure. 


\section{The EU policy on the extension of the Convention on a Common Transit Procedure and NCTS}

Currently, transit procedures within the EU and neighboring European countries are functioning within three multilateral legal regimes based on different law sources. Nevertheless, said systems are primarily complementing or overlapping each other. The list of such transit systems includes:

- Community Transit utilized solely by the EU Member States and also extended to the territories of Andorra and San Marino; and thus, based upon the Union Customs Code and other EU customs legislation;

- Common Transit covering the transit between the EU, four EFTA countries, United Kingdom, Serbia, Northern Macedonia, and Turkey, based upon the Convention on A Common Transit Procedure and Convention on The Simplification of Formalities in Trade in Goods, both of 20 May 1987;

- Transports Internationaux Routiers (TIR) system for about 60 contracting parties of the 1975 Transit Convention.

In their present form, the first two, Community Transit and Common Transit systems, provide an entirely paperless environment for customs authorities and traders involved due to utilizing the single New Computerized Transit System (NCTS). The NCTS automates all transit formalities and internal customs authorities' processes due to adapting harmonized electronic messaging and interconnected national computerized transit systems and users' applications. The NCTS is the product of the EU institutions in terms of development, regulation, and control of implementation; and it is mandatory for all operators lodging transit declarations within the scope of the two said transit systems, regardless of the mode of transport concerned (i.e., air, sea, road, or rail), except the cases where a commercial document serves as the transit declaration (European Union Customs Transit Including Arrangements With Neighbouring Countries Under The Common Transit Convention). 
At the same time, the TIR system emerged as a paper-based system utilizing books of vouchers, and its electronic version has been in development; so far, goods under TIR must be declared to the NCTS if they enter the Common or Community Transit areas (Guide On Establishing an Automated Customs Transit Transport System).

Generally speaking, the emergence of the NCTS was the attempt of the EU authorities to answer challenges of massive fraud that existed transit procedures faced at the beginning of 1990th due to vulnerability of validation of paper documents and poor management of guaranties. In particular, those problems were caused by the low capacities of customs services of neighboring eastern countries. To a remarkable extent, findings on the issues of the first EU Parliamentary Enquiry Committee became a driver that forced the EU Member States and Common Transit Convention members to computerize the Community Transit and Common Transit regimes that resulted in modernized regulations came into force on 1 May 2004 launching NCTS (Groenendijk, 2018).

It is possible to characterize NCTS as a "fully computerized customs regime," applied to the goods placed under Community or Common transit procedures, that was designed to address two main issues specifically:

- strengthening and modernizing the means of customs control in the context of the European Single Market and the associated countries (EFTA),

- reducing the possibilities for fraudulent operation inherent in the former paper-based (Automatic Customs Transit Transport Systems In Operation (NCTS, ACTS, TIM).

With this respect, it is possible to speak of NCTS as a specific "legal regime inside the legal regime," where rules of the Community Transit or Common Transit procedures comprise the external legal framework for transporting goods in transit, and the NCTS regulations, standards, and specification comprise legal 
frameworks for internal processes of placing goods under the respective procedure.

Moreover, the crucial point is that the NCTS legal framework is derived not from the multilateral international agreements but the secondary EU legislation. Nevertheless, the Convention on a Common Transit Procedure refers to the NCTS, and it clearly points out the hegemony role of the EU institutions in drafting all rules governing the functioning of this system. For example, Article 25 of Title I of said Convention "Transit declarations by means of electronic data-processing techniques" provides that the particulars and the structure of the data of the transit declaration shall be applied "as of the dates of deployment of the upgrading of the New Computerised Transit System ('NCTS') referred to in the Annex to Commission Implementing Decision (EU) 2016/578" (Convention on a Common transit procedure. Consolidated text).

Thus, the EU provides both the legal and the institutional framework for the NCTS implementation and application throughout all States that are parties of the Convention on a Common Transit Procedure. Whereas the legal framework for NCTS comprises the Union Customs Code and other EU secondary legislation; the institutional framework is managed by the European Commission's Directorate General of Taxation and Customs Union (DG TAXUD), which is responsible for managing the standard electronic reference data for NCTS, and ensuring that the common secure data network is available at regional level (Guide On Establishing an Automated Customs Transit Transport System).

Once again, the NCTS should not be viewed as a mere instrumental dimension limiting its functions to automating and digitalizing the Community Transit and Common Transit procedures. Even at the very beginning of the deployment of the EU centralized customs IT solutions, there were suggestions that due to the "essentially outward-looking nature of the EU's customs union", respective customs reforms were going remarkable beyond mere Customs 
Union issues. They instead manifested divorce of customs rules from single market measures with the focus to promoting or impeding "progress towards the competitive society that the EU has set as its goal" (Wilmott, 2007, p. 12).

To that end, the whole NCTS story also plays an essential role within the EU external policy because rules and demands on its implementation significantly affect procedures and day to day businesses of all customs authorities involved, irrespectively whether there are authorities of the EU Member-States or authorities of the Non-Member parties to the Convention on a Common Transit Procedure. From the very beginning, the whole EU e-Customs project was considered as the central pillar of pan-European eGovernment strategy, in which customs procedures based on $\mathrm{UN} / \mathrm{CEFACT}$ standards framework were embedding in a serviceoriented architecture for Collaborative eGovernment (Vogel et al., 2008). Implementing the NCTS, as well as other EU e-Customs solutions that "builds on a long and successful European history on technology and innovation," makes national customs services update their conventional workflow, in particular by applying specific managerial tools, such as process thinking in lean innovation (Dalton \& Stosic, 2021). Hence, the EU utilizes the NCTS as an additional channel of exporting general principles of its administrative system.

Besides, many pieces of research suggest that the implementation of regional ICT solutions into customs procedures potentially promotes the rule of law in performances of the national customs administration involved and provides traders with a predictable, consistent trade compliance environment they can operate within (Chow, 2018, p. 3). From this point of view, the NCTS, with its supranational administration and a strong emphasis on the counteraction fraud and protection of financial interests of the participating States, comprises such an electronic compliance environment for transit procedures. The supranational administration and information exchange between different national customs administrations narrows possibilities for 
certain negative national peculiarities to influence the processes. At the same time, traders get clear and harmonized compliance rules with predictable outcomes.

In addition, the accession to the Convention on a Common Transit Procedure is the part of legislation alignment between the EU and a candidate State in a process of latter's preparation to the accession. Due to the EU accession criteria under the Chapter 29 "Customs Union" the full implementation of the Community Transit Procedure requirements including developing an automated transit system compatible to the NCTS is the one of mandatory pre-requirements for the applying for membership (Strategy for Implementation of Common Transit System NCTS (New Computerised Transit System) for The Republic of Macedonia).

Considering that, the States participating in the Convention on a Common Transit Procedure, depending on their general level of integration with the EU, may be divided into four categories: the EU Member States, the EFTA Members, candidate countries, and other transit countries. The particular approach was articulated in the Commission Communication "Strategy to prepare certain neighbouring countries for accession to the 1987 EC-EFTA Conventions on a common transit procedure and the simplification of formalities in trade in goods" of 2010, which emphasized difference of the EU interests for extending the Common Transit to different integration processes.

For example, concerning candidate countries, para 1.5 of the Commission Communication mentioned above defines extending the Conventions to other countries able to implement them as such that "is clearly in the interest of the Union and European traders and will promote alignment with the relevant EU acquis in the region". While the extension of the Conventions to the other European countries (para 2.1) is considered within the interest of the EU in line with the European Neighbourhood Policy and Eastern Partnership as a part of "legislative approximation in the area of customs and capacity 
building and modernization, including computerization". Here the focus shifts to the promotion of trade facilitation and reduction of border congestion.

The precise identification of the EU interest in extending the Common Transit to a broader range of countries triggers the EU assistance to these states in reaching redness on the legal, operational, and computerization levels, including alignment of the legislation, fulfilling practical and financial requirements, and deployment a computerized transit system. That, notably, includes the EU measures "to ensure the overall consistency of the preparations with the implementation of customs instruments on legislation and integrated application at the administrative level" (para 2.4).

Hereby, extending Common Transit and implementing NCTS has moved far beyond associated states, where it is an essential part of the functioning of the Deep and Comprehensive Free Trade Areas (DCFTA). Currently, the issue is pursued within the frameworks of the EU Neighborhood policies to improve border management and trade facilitation and provide proper balance with an efficiency of customs controls. For example, the Eastern Partnership countries have the following status of NCTS implementation:

- Armenia - the status is unknown;

- Azerbaijan - NCTS is in progress. Technical assistance by EU financed Twinning project;

- Belarus - the status is unknown;

- Georgia - NCTS is in progress. Technical assistance by EU financed Twinning project;

- Moldova - NCTS is in progress. Technical assistance by EU financed Twinning project. Obligation according to CEFTA agreement;

- Ukraine - NCTS is in progress. EU financed project. Obligation according to EU Association agreement (EU4Digital. R.3.4-3 Analysis and selection of Eastern partner countries to pilot mechanisms of exchange of information). 
It is possible to see from the list above that only the countries involved in Eurasian Customs Union skip the opportunity to implement NCTS. Furthermore, the remarkable point is that obligations or intentions to implement NCTS derives from different international instruments, like the EU-funded projects supporting Integrated Border Management, the pre-accession regional trade agreement, and obviously from EU association agreements. Such differentiation in the instruments for approximation of procedures shows the variety of the EU approaches to pursuing its external policies and the suitableness of the Common Transit and its IT solutions for different types of European integration.

\section{Peculiarities of NCTS implementing}

Ukrainian obligations towards alignment its legislation with a Common Transit Procedure arose from Annex XV to Chapter 5 of the EU - Ukraine Association Agreement (AA). Its provisions set that Ukraine was to incorporate the 1987 Convention on a Common Transit Procedure and the supplementing 1987 Convention on the Simplification of Formalities in Trade in Goods within one year following the entry into force of AA. However, the respective deadline, which expired on September 1, 2018, was not met.

To grasp the starting conditions for Ukraine's path towards the full scale acceding the Common Transit Procedure and NTCS, it is worse reminding that the core of said procedure consists in the direct exchange of technical messages and customs information between customs administrations of different countries on the route of a particular transit movement. To that end, an indicative is a fact that currently, possibilities of Ukrainian customs authorities for information exchange are minimal and based upon bilateral agreements, which is described in the table below (Table 1). 


\begin{tabular}{|c|c|c|}
\hline \multicolumn{3}{|c|}{$\begin{array}{c}\text { Customs Information Exchange between Ukraine } \\
\text { and Neighbor Countries }\end{array}$} \\
\hline $\begin{array}{l}\text { Neighboring } \\
\text { Country }\end{array}$ & $\begin{array}{l}\text { Existing customs } \\
\text { information } \\
\text { exchange practice }\end{array}$ & $\begin{array}{l}\text { Volume of existing } \\
\text { information exchange }\end{array}$ \\
\hline Azerbaijan & $\begin{array}{l}\text { Information is being } \\
\text { exchanged based on } \\
\text { the bilateral protocol. }\end{array}$ & $\begin{array}{l}\text { Export, transit declaration (full } \\
\text { data set). Automatic matching. }\end{array}$ \\
\hline Belarus & $\begin{array}{l}\text { PRINEX (Electronic } \\
\text { System of Pre- } \\
\text { arrival Information } \\
\text { Exchange). }\end{array}$ & $\begin{array}{l}\text { Export, transit/entry summary } \\
\text { real time exchange in xml } \\
\text { format. Automatic matching. }\end{array}$ \\
\hline Hungary & $\begin{array}{l}\text { Information is being } \\
\text { exchanged based on } \\
\text { the bilateral protocol. }\end{array}$ & $\begin{array}{l}\text { Export, transit declaration } \\
\text { (consignment ID number, } \\
\text { date and time of exit, vehicle } \\
\text { registration number, customs } \\
\text { tariff number, description and } \\
\text { weight of the consignment). } \\
\text { Real time exchange in xml } \\
\text { format. }\end{array}$ \\
\hline Moldova & $\begin{array}{l}\text { Information is being } \\
\text { exchanged based on } \\
\text { the bilateral protocol. }\end{array}$ & $\begin{array}{l}\text { Export, transit declaration (full } \\
\text { data set). Automatic matching. }\end{array}$ \\
\hline Poland & $\begin{array}{l}\text { Information is being } \\
\text { exchanged based on } \\
\text { the bilateral protocol. }\end{array}$ & $\begin{array}{l}\text { Pilot project at border crossing } \\
\text { point Hrebene (PL) - Rava } \\
\text { Russka (UA). Automatic } \\
\text { real-time exchange of data on } \\
\text { transport means (registration } \\
\text { number of transport, weight, } \\
\text { sign: empty/full). Data } \\
\text { direction only from PL to UA. }\end{array}$ \\
\hline
\end{tabular}

Table 1. As-is situation in Ukraine with customs information exchange, after EU4Digital (2019) Analysis and selection of Eastern partner countries

to pilot mechanisms of exchange of information (EU4Digital. R.3.4-3

Analysis and selection of Eastern partner countries to pilot mechanisms of exchange of information) 
Table 1 shows that Ukraine's current international customs information exchange is not harmonized both in terms of formats and data sets. In addition, it is limited towards customs checkpoints involved, and directions of data flow in some cases. Such a situation results in comparatively low effectiveness of utilization of information received for customs control purposes.

To that end implementing NCTS and a full-scale accession to the Common Transit Procedure would be of exceptional interest of Ukrainian authorities. Such an interest considering compliance enforcement instruments provided by NCTS embraces two major spheres.

Firstly, the direct automated, standardized, and harmonized data exchange between Ukrainian customs and customs authorities of all parties of the Convention on a Common Transit Procedure will decrease fraudulent actions with accompanying documents. Secondly, analysis of risks related to the movement of goods will also be significantly improved, and therefore, the number and timing of procedures during customs clearance and customs control will be reduced (Customs Service is testing NCTS). Both those issues are at great importance for Ukraine, considering on the one hand the extraordinary role of customs revenue in total tax revenue, which reaches up to $45 \%$, and on the other hand businesses complains of excessive and time-consuming customs and other border formalities.

The accession process to the Convention on A Common Transit Procedure comprises five subsequent steps (Karabulut, 2013). The first one consists of fulfilling preconditions, including developing the national legislation, deploying a national transit system compatible with the actual phase of the NCTS, and making that procedure operational. The second step envisages the national application of a Common Transit Procedure. At the third step, the EU and EFTA countries conduct conformity evaluation, including site visits by DG TAXUD. At the last two steps, the current Contracting Parties to the Convention on a Common Transit Procedure decide 
on an invitation to join the Convention, and the proper instrument of accession is signed.

It is worth noting that Ukraine had relatively better start conditions for implementing NCTS because of the long enough experience of utilizing computerized systems of customs clearance and electronic declaring. Moreover, in 2018 Ukrainian customs launched the full-scale application of the Single Window (Law of Ukraine On Amending the Customs Code of Ukraine and Some Other Laws of Ukraine Concerning Introduction of The Mechanism Of "Single Window" and Optimization of Application of Control Procedures for the Movement of Goods Across Customs Border of Ukraine, 2018); thus, both customs officials and traders got used to paperless procedures as a business as usual. On contrary, for example, for Serbia, which implemented the NCTS in 2016, the common transit procedure became the first electronic Customs procedure ever introduced in the country (Protic, 2019).

However, Ukraine missed the deadline set by the AA. The Law on the Regime of Common Transit and Introduction of National Electronic Transit System No. 78-IX was passed only in 2019 and came into force on March 25, 2020. Law 78-IX implements the rules of the Convention on A Common Transit Procedure and is to be in force until Ukrainian accession to the Convention. Also, Law 78-IX creates the legal frameworks for the national application of the electronic transit system for data exchange between the Ukrainian customs authorities under the common transit procedure.

Implementing NCTS is a primarily instrumental issue, which demands from the State allocating appropriate recourses and performing a vast amount of preparation work. There are at least four main instruments that should be in place to support the deployment and operation of NCTS: 1. Legal base; 2. Telecommunication network connecting customs authorities; 3. IT applications for customs and traders to perform exchange of messages; Central 
Help Desk (CHD) and a Technical Centre (TC) to monitor and to support the NCTS operation (Automatic Customs Transit Transport Systems In Operation (NCTS, ACTS, TIM).

To that end, the first Roadmap on Ukraine's accession to the Common Transit Procedure, primarily focusing on preparation for the national application of the common transit procedure, was approved in September 2018. The fulfillment of that Roadmap was to go through four phases, including customs procedures implementation, IT implementation, training, and rollout (Action roadmap on Ukraine's accession to the EU/EFTA common transit procedure). Additionally, implementing NCTS was included in the Strategy for Integrated Border Management up to 2025, approved by the Cabinet Ministers of Ukraine. Within the strategic goal of optimizing border procedures and granting security, that Strategy emphasized task of the promoting cross-border cooperation, including "ensuring the development of mechanisms for the exchange of information on goods with the customs services of neighboring countries; and taking steps for joining the electronic declaration system (NCTS)" (Order of the Cabinet of Ministers of Ukraine "On approval of the Strategy of integrated border management for the period up to 2025", 2019). These tasks were also clarified in the Action plan for 2020-2022 on the implementation of the Strategy of Integrated Border Management, which envisaged the development of proper secondary legislation, as well as a rolling out respective IT solutions at the expense of the EU Public Finance Management Support Program for Ukraine (EU4PFM) (Order of the Cabinet of Ministers of Ukraine "On approval of the action plan for 2020-2022 to implement the Strategy of Integrated Border Management for the period up to 2025", 2019).

The 2021 European Parliament Resolution on the AA's implementation (para 131), in particular, noted the progress in the alignment of Ukrainian customs and border procedures to those of the Union and welcomed the Law on the introduction of the 
National Electronic Transit System (NCTS), Strategy for integrated border management up to 2025 and the subsequent 2020-2022 action plan. However, it urges the Ukrainian authorities to adopt all the extraordinary measures and regulations needed to operationalize the NCTS system fully (European Parliament resolution of 11 February 2021 on the implementation of the EU Association Agreement with Ukraine (2019/2202(INI)).

It is also worth mentioning that the EU - Ukraine AA was drafted before the Russian aggression of 2014; hence, it is currently impossible to extend the Common Transit Procedure to the whole Ukrainian territory. The territories of occupied Crimea and temporary frozen low-intensity conflict in the Donetsk and Luhansk regions (Galbreath \& Malyarenko, 2020) will be excluded indefinitely. However, neighboring Moldova has an experience extending of DCFTA, including all respective customs procedures to the territory of frozen conflict in Transnistria (Kemoklidze \& Wolff, 2020).

\section{National application of the Common Transit \\ Procedure and NCTS}

Ukraine's adaptation of the Common Transit Procedure consists of three subsequent stages: Piloting project, National application, and International application. The Piloting project took place from November 2020 through March 16, 2021, and involved four territorial customs authorities (Volyn Customs, Kyiv Customs, Northern Customs, and Odesa Customs) (Common Transit Regime). During that period, traders voluntarily registering for the Piloting project could lodge a dedicated type of customs declaration (transit T1UA) alongside advanced customs declaration (IM EE) used for conventional national transit. Thus, the newly deployed Electronic Transit System (ETS), the national analog of the NCTS, has been tested. Respectively from March 17, 2021, the stage of the National application of ETS was announced. From that point, traders 
have received an option to choose between placing goods under a common transit procedure and utilizing a conventional national transit procedure.

The EU support to the implementation of the Common Transit Procedure is financed through the European Neighbourhood Instrument (ENI) under the Public Finance Management Support Programme for Ukraine - EU4PFM ENI/2017/040-426, which has been jointly cofinanced by Swedish International Development Agency (SIDA) and Lithuania (Financing Agreement ENI/2017/040-426).

Before and during the piloting stages, the authorities involved made needed arrangements to make the ETS operational. In particular, from 2020 through 2021, Ukrainian authorities have issued a significant pile of secondary legislation to create a regulative environment for the national application of the Common Transit Procedure and ETS. This legislation covers all critical aspects of the implementation and application of the Common Transit. However, from the start, the proper tasks were divided between the Cabinet of Ministers, Ministry of Finance, and State Customs Service; thus, in most cases, a single area received a few legislative acts partly governing the same issues.

For example, the form of declaration, proper data sets, and lodging procedure is regulated by the three acts of the secondary legislation on the Common Transit, which include:

- Resolution of the Cabinet of Ministers of Ukraine of August 5, 2020, No. 681 "Some issues related to the use of customs declarations of certain types";

- Order of the Ministry of Finance of December 22, 2020, No. 795 "On approval of the Procedure for filling out customs declarations of certain types";

- Order of the State Customs Service of January 11, 2021, No. 7 "On approval of forms and data sets of electronic messages of the common transit regime". 
Also, the same subjects issued three different acts to develop a system of guarantees for a customs debt payment that deals with establishing financial guarantors and managing different types of financial guarantees. This group of secondary legislation acts includes:

- Resolution of the Cabinet of Ministers of Ukraine of July 8, 2020, No. 619 "Some issues of independent financial intermediaries";

- Order of the Ministry of Finance of Ukraine of February 9, 2021, No. 69 "On approval of the Procedure for information exchange on registration of a financial guarantor, its suspension, renewal, cancellation, other information necessary for supervision and control over compliance with the financial guarantor's conditions of financial guarantor status";

- Order of the Ministry of Finance of April 6, 2021, No. 200 "On some issues of ensuring the payment of customs debt in joint transit".

Finally, there acts that, respectively, clarify provisions of the Law on Common Transit concerning internal procedural aspects and internal processes of customs authorities while applying rules of common transit, administrating transit simplifications, which may be granted to traders, and operation of the Help Desk service in support of traders placing their goods under procedure:

- Order of the Ministry of Finance of Ukraine of February 12, 2021, No. 86 "On approval of the Procedure for customs formalities in the application of the common transit regime using the electronic transit system and the Procedure for admission of vehicles and containers for transportation of goods under customs seals in the common transit regime";

- Resolution of the Cabinet of Ministers of Ukraine of August 12, 2020, No. 705 "Some issues of granting permission for the use of special transit simplification";

- Order of the State Customs Service of Ukraine dated 05.03.2021 No. 159 "On approval of the Procedure for the support service for common transit of the State Customs Service". 
As for the deployment of proper IT solutions for electronic data exchange, the Government of Lithuania provided the Customs Service of Ukraine with its NCTS software free of charge (Common Transit Procedure (NCTS)). With the financial support of EU4PFM, that software was localized and adapted for use in Ukraine, becoming the Ukrainian ETS. The localization of the software comprised translation in Ukrainian and integration for different degrees with specific modules of Ukrainian Automates System of Customs Clearance, including program "Inspector-2006" utilized by customs authorities, portal "Single Window for International Trade", Automated Risk Assessment and Management System, the CheckPoint Journal, which is supposed to provide a smooth transition from the conventional transit procedure to the Common Transit. Additionally, the customs offices primarily involved in the clearance of imports from the EU got interconnections to ETS, and officials received proper training. As for July 2021, the ETS is in use only at the checkpoints for road vehicles, whilst the rail-road ones are not in demand so far.

Ukrainian government counts on meeting all the necessary requirements for acceding to the Convention on a Common Transit Procedure and thus to moving towards international application of ETS by the end of 2021 (Alisauskas, 2021), while the NCTS will still transition between Phase 4 and Phase 5. If doing so, the decision on accepting Ukraine to join the Convention may be expected in 2022. Otherwise, considering the EU plans to complete the transition to the NCTS Phase 5 in the fourth quarter of 2023, and to the NCTS Phase 6 in second quarter of 2025 (Commission Implementing Decision (EU) $2019 / 2151$ establishing the work programme relating to the development and deployment of the electronic systems provided for in the Union Customs Code, 2019), Ukraine's accession to the Convention may be likely delayed up to the end of 2025. In particular such delay may emerge due to different standards on information exchange, data sets, and upgraded interfaces of the NCTS 
Phase 5; and interconnection with the developed new iteration of the EU Import Control System of the NCTS Phase 6 that would be hard to catch. However, specific arrangements towards the compatibility of Ukrainian ETS with the subsequent phases of the NCTS have been made. To that end, the Public Institution Central Project Management Agency of the Republic of Lithuania (CPMA), which initially provided software for Ukrainian ETS, is planning to procure services on the Development of NCTS Phase 5 compatible national transit application for the State Customs Service of Ukraine (Call to participate in the market consultation on the Development of NCTS Phase 5 compatible national transit application).

Nevertheless, the overall Ukrainian government's approach to implementing the EU standards into the national customs legislation shows extensive complicity in regulative framework and preconditions for different authorizations provided within respective procedures. The issue, in particular, consists in a general tendency of Ukrainian rule-makers to shift attention to possible abuse of the law and the protection of the State's fiscal interests (Gayk et al., 2021, p. 61), so that the ideas of simplifications pretty often become distorted showing only formal alignment with the EU legislation.

The most significant problem that applicants for AEO status in Ukraine have already met and applicants for "authorized consignor" and "authorized consignee" statuses will meet is non proportionally strict criteria of financial solvency. In Ukraine, the applicant's financial solvency is checked by formally calculating the coefficients and confirming the absence of tax debt. The procedure for assessing compliance with the criterion of sound financial condition does not involve analysis of additional documents or factors that influenced the calculation. Hence, even Ukrainian subsidiaries of global companies receiving long-term loans from the latter have failed to meet the legislation criteria, similar to AEO and transit simplifications (Miroshnychenko, 2021). 
In addition, the current Ukrainian system of guarantees is more liberal than the one provided within the frameworks of Common Transit. Due to the Resolution of the Cabinet of Ministers of Ukraine of May 21, 2012, No. 461, only selected types of goods imported or brought on customs territory of Ukraine under transit procedure are subject to provision of guarantees. Such rules concern about $30 \%$ of all transit covered by preliminary customs declarations, while most common declarations type EE are freed from a guarantee's submission. Contrary, a Common Transit Procedure demands submitting a guarantee in all cases, except a trader granted transit simplifications, which is the issue discussed above.

This resulted in a low attractiveness of such "approximated" procedures for traders. For example, for the year of the AEO program operation in Ukraine, only three applications have been submitted, and only one applicant has obtained authorization. Similarly, due to the customs service data for the two months of national application (March 17, 2021, through June 17, 2021), only 130 traders registered at the dedicated "Trade made easy" portal and lodged in aggregate 122 declarations T1UA, which is shallow figures considering 2.500 customs officials involved into the functioning of ETS (Demchenko, 2021). For the compaction, for the six-month 2021, Ukrainian customs authorities processed a total of 2.4 million customs declarations, including 232.000 transit declarations (Declaration Rates 06-month 2021).

The Ukrainian government utilizes a kind of coercive methodology, which consists of withdrawing existing simplifications for businesses not transitioning to the new AEO and Common Transit programs. Most importantly, there is a discontinuing from November 2022 a preliminary customs declaration (known as type EA) starting, which allows declarants to take the goods to their premises directly without presenting them to the Customs office (Gayk et al., 2021, p. 61). Since that such an option will be available only for AEO-C and Authorized consignees under a Common Transit Procedure. Thus, 
not to lose existing simplifications appears to be the only traders' motivation for transition to said programs so far, which questions the quality of Ukrainian actions on the approximation to the EU customs legislation.

\section{Conclusions}

Accession to the Convention on a Common Transit Procedure, a Ukrainian obligation under AA, may potentially solve the issues of streaming performance of customs and border formalities in the trade between the EU and Ukraine. The implementation of the NCTS also addresses the revenue protection concerns of the Ukrainian government, which makes this objective of mutual interest of both parties. However, attempts to emphasize revenue concerns significantly distort the simplification part of a Common Transit Procedure, which resulted in excessively rigorous rules of national legislation on granting simplifications. Moreover, the attempts to increase the attractiveness of new procedures for traders by discontinuing existing simplifications highlight such a distorted approach of Ukrainian rule-makers. So far, the phase of the national application reveals the low popularity of Common Transit Procedure in terms of the number of traders applying and the number of customs declarations lodged. However, the process may accelerate if Ukraine manages to accede to the Convention on a Common Transit Procedure in 2022, as planned. Otherwise, there emerge additional difficulties due to the transition to the NCTS Phase 5 and Phase 6. In combination with relatively limited usage of procedure in the national application, this may lead to significant delays in fullscale utilization of NCTS in the movement of goods and means of transport between Ukraine and the current Common Transit area.

\section{REFERENCES}

Alisauskas, V. (2021). The EU supports Ukraine's accession to the Convention on a Common Transit Procedure. EU4PFM. https://eu4pfm.com.ua/interviews/ 
the-eu-supports-ukraine-s-accession-to-the-convention-on-a-common-transitprocedure/\#more-2334

Automatic Customs Transit Transport Systems In Operation (NCTS, ACTS, TIM). https://cutt.ly/zmKxBCo

Butin, A., \& Shulga, D. (2019). Streamlining EU-Ukraine Customs Procedures. Civic Synergy Project. https://www.civic-synergy.org.ua/wp-content/ uploads/2018/04/STREAMLINING-EU-UKRAINE-CUSTOMSPROCEDURES_en_2019.pdf

Call to participate in the market consultation on the Development of NCTS Phase 5 compatible national transit application. EU4PFM. https://eu4pfm.com.ua/ news/call-to-participate-in-the-market-consultation-on-the-development-ofncts-phase-5-compatible-national-transit-application/

Chow, N. (2018). The Single Window and the TFA: ASEAN's Best Chance at a Common Rule of Law. Asian Journal of Law and Economics, 9, 2. DOI: 10.1515/ajle-2017-0022

Common Transit Procedure (NCTS). State Customs Service of Ukraine. https://customs.gov.ua/rezhim-spilnogo-tranzitu-ncts [in Ukrainian].

Common Transit Regime. Ministry of Finance of Ukraine. https://www.mof.gov.ua/uk/common_transit_mode-473 [in Ukrainian].

Customs Administration of the Republic of Macedonia. (2010, November). Strategy for Implementation of Common Transit System NCTS (New Computerised Transit System) for The Republic of Macedonia. Ver. 1.0-EN. http://oldweb.customs.gov.mk/en/Uploads/NCTS_STRATEGY_2010_TO_ DG_TAXUD_from_CARM_FINAL\%20_5_.pdf

Customs Service is testing NCTS. EU4PFM. https://eu4pfm.com.ua/news/ customs-service-is-testing-ncts/

Dalton S., \& Stosic B. (2021) The Importance of Applying Lean Innovation for Enhancing Harmonization of Customs Procedures in context of Digitalization of Customs Administration - A Case Study of Serbia. Lex Localis, 19, 2, 305-327. DOI: 10.4335/19.2.305-327(2021)

Demchenko, S. (2021) Implementation of all components necessary for Ukraine's accession to the Convention on the procedure of joint transit in 2022, is on an agreed schedule and in cooperation with European experts. State Customs Service of Ukraine. https://clck.ru/WBP7g [in Ukrainian].

EFTA countries. (1987, May 20). Convention on a Common transit procedure. Consolidated text. 01987A0813(01)-EN-01.01.2021-007.001. EUR-Lex. http://data.europa.eu/eli/convention/1987/415/2021-01-01 
EU4Digital. (2019, December 20). R.3.4-3 Analysis and selection of Eastern partner countries to pilot mechanisms of exchange of information. https://eufordigital.eu/wp-content/uploads/2020/06/eCustoms-Confirmed-listof-pilot-countries.pdf

European Neighbourhood Instrument (ENI). Programme Statements. DB2021. https://cutt.ly/NmKc9GJ

Galbreath, D., \& Malyarenko, T. (2020). Evolving Dynamics of Societal Security and the Potential for Conflict in Eastern Ukraine. Europe-Asia Studies, 72, 2, 209-237. DOI: 10.1080/09668136.2019.1705964

Gayk, A., Naujoke, E., \& Kormych, B. (2021). Harmonization of Procedures Is Still Work in Progress. WCO News, 94, 58-61.

Governmental office on Coordination of European and Euro-Atlantic Integration of Secretariat of Cabinet of Ministry of Ukraine, Ministry of Finance of Ukraine, State Fiscal Service of Ukraine. (2018, September 28). Action roadmap on Ukraine's accession to the EU/EFTA common transit procedure. http://sfs.gov.ua/data/files/229681.pdf [in Ukrainian].

Grainger, A. (2014). Trade and customs compliance costs at ports. Maritime Economics \& Logistics, 16, 4, 467-483.

Groenendijk, J.P. (2018). Customs transit procedures: insights from an operator. WCO News, 85. https://mag.wcoomd.org/magazine/wco-news-85/ customs-transit-procedures-insights-operator/

Karabulut, E. (2013). Common Transit System and NCTS "Fast, Easy, Secure, Economic". TRACECA. http://www.traceca-org.org/uploads/media/ TURKEY_KIEV_NCTS_1.pdf

Kemoklidze, N., \& Wolff, S. (2020). Trade as a confidence-building measure in protracted conflicts: the cases of Georgia and Moldova compared. Eurasian Geography and Economics, 61, 3, 305-332. DOI: $10.1080 / 15387216.2019 .1702567$

Miroshnychenko, V. (2021). Simplification of customs procedures: changes needed: Why only one company received the status of an authorized economic operator and what needs to be changed. Ekonomichna Pravda. https://www.epravda.com.ua/columns/2021/07/9/675807/ [in Ukrainian].

Popa, I., Belu, M., Paraschiv, D., \& Marinoiu, A. (2015). Best Practices in Customs Procedures. Amfiteatru Economic Journal, 17, 40, 1095-1107. http://hdl.handle.net/10419/168967 
Protic, O. (2019). Serbia's accession to the common transit procedure has become a real game changer. WCO News. https://mag.wcoomd.org/magazine/ wco-news-88/serbia-ncts/

The Cabinet of Ministers of Ukraine. (2019, December 27). On approval of the action plan for 2020-2022 to implement the Strategy of Integrated Border Management for the period up to 2025: Order (No. 1409-r). https://zakon.rada.gov.ua/laws/show/1409-2019-p\#Text [in Ukrainian].

The Cabinet of Ministers of Ukraine of (2012, May 21) On approval of the list of goods imported into the customs territory of Ukraine and/or moved through the territory of Ukraine under through-passing transit and internal transit subject to the mandatory provision to customs authorities a guarantee of the payment of customs duties: Resolution (No. 461) https://zakon.rada.gov.ua/ laws/show/461-2012-п\#Text [in Ukrainian].

The Cabinet of Ministers of Ukraine. (2019, July 24). On approval of the Strategy of integrated border management for the period up to 2025: Order (No. 687-r). https://zakon.rada.gov.ua/laws/show/687-2019-p\#Text [in Ukrainian].

The Cabinet of Ministers of Ukraine. (2020, August 12). Some issues of granting permission for the use of special transit simplification: Resolution (No. 705). https://zakon.rada.gov.ua/laws/show/705-2020-п\#Text [in Ukrainian].

The Cabinet of Ministers of Ukraine. (2020, July 8). Some issues of independent financial intermediaries: Resolution (No. 619). https://zakon.rada.gov.ua/ laws/show/619-2020-п\#Text [in Ukrainian].

The Cabinet of Ministers of Ukraine. (2020, August 5). Some issues related to the use of customs declarations of certain types: Resolution (No. 681). https://zakon.rada.gov.ua/laws/show/681-2020-п\#Text [in Ukrainian].

The European Commission. (2019, December 13). Establishing the work programme relating to the development and deployment of the electronic systems provided for in the Union Customs Code: Implementing Decision (EU) 2019/2151). OJ. 16.12.2019. L135/168. https://eur-lex.europa.eu/ legal-content/EN/TXT/PDF/?uri=CELEX:32019D2151\&from=EN

The European Commission. (2010, November 18). Strategy to prepare certain neighbouring countries for accession to the 1987 EC-EFTA Conventions on a common transit procedure and the simplification of formalities in trade in goods: Communication to the European Parliament and the Council (COM/2010/0668final). EUR-Lex. https://eur-lex.europa.eu/legal-content/EN/ ALL/?uri=CELEX:52010DC0668 
The European Parliament. (2021, February 11). On the implementation of the EU Association Agreement with Ukraine: Resolution (2019/2202(INI). https://www.europarl.europa.eu/doceo/document/TA-9-2021-0050_EN.pdf

The Government of Ukraine represented by the Ministry of Economic Development and Trade, the European Commission. (2018, December 12). Financing Agreement (ENI/2017/040-426). https://www.me.gov.ua/Files/ GetFile?lang=uk-UA\&fileId=3240aa95-afd6-475d-89b8-4f03eb7ad368

The Ministry of Finance of Ukraine. (2021, February 12). On approval of the Procedure for customs formalities in the application of the common transit regime using the electronic transit system and the Procedure for admission of vehicles and containers for transportation of goods under customs seals in the common transit regime: Order (No. 86). http://zakon.rada.gov.ua/laws/show/ z0249-21\#Text [in Ukrainian].

The Ministry of Finance of Ukraine. (2020, December 22). On approval of the Procedure for filling out customs declarations of certain types: Order (No. 795). https://zakon.rada.gov.ua/laws/show/z0076-21\#Text [in Ukrainian].

The Ministry of Finance of Ukraine. (2021, February 9). On approval of the Procedure for information exchange on registration of a financial guarantor, its suspension, renewal, cancellation, other information necessary for supervision and control over compliance with the financial guarantor's conditions of financial guarantor status: Order (No.69). https://zakon.rada.gov.ua/laws/show/z0444-21\#Text [in Ukrainian].

The Ministry of Finance of Ukraine. (2021, April 6). On some issues of ensuring the payment of customs debt in joint transit: Order (No. 200). https://zakon.rada.gov.ua/laws/show/z0648-21\#Text [in Ukrainian].

The State Customs Service of Ukraine. (2021). Declaration Rates 06-month 2021. https://customs.gov.ua/web/content/4434? unique=9e72dc6b5e3a926286e $85 \mathrm{f} 48 \mathrm{e} 4 \mathrm{e} 1051 \mathrm{db} 217 \mathrm{~b} 25 \mathrm{a} \&$ download=true

The State Customs Service of Ukraine. (2021, January 11). On approval of forms and data sets of electronic messages of the common transit regime: Order (No. 7). https://customs.gov.ua/documents/pro-zatverdzhennia-formta-naboru-danikh-elektronnikh-povidomlen-rezhimu-spilnogo-tranzitu-156 [in Ukrainian].

The State Customs Service of Ukraine. (2021, March 5). On approval of the Procedure for the support service for common transit of the State Customs Service: Order (No. 159). https://customs.gov.ua/en/documents/prozatverdzhennia-poriadku-roboti-sluzhbi-pidtrimki-z-pitan-spilnogo-tranzituderzhmitsluzhbi-200 [in Ukrainian]. 
The Union Transit Procedure (including TIR) and the Customs Status of Goods. Irish Tax and Customs. https://revenue.ie/en/customs-traders-and-agents/ documents/transit-trader-guide.pdf

Transit Guidelines. Route for efficient transit regime. 2017. World Customs Organization. Brussels. https://cutt.ly/wmKvx77

United Nations Economic Commission for Asia and the Pacific. (2016). Guide On Establishing an Automated Customs Transit Transport System. 2016. https://cutt.ly/ymKclFo

Verkhovna Rada of Ukraine. (2018, September 6). On Amending the Customs Code of Ukraine and Some Other Laws of Ukraine Concerning Introduction of The Mechanism Of "Single Window" and Optimization of Application of Control Procedures for the Movement of Goods Across Customs Border of Ukraine: Law of Ukraine. (No. 2530-VIII). https://zakon.rada.gov.ua/laws/ show/2530-19\#Text [in Ukrainian].

Verkhovna Rada of Ukraine. (2019, September 12). On the regime of common transit and introduction of the national electronic transit system: Law of Ukraine (No. 78-IX). https://zakon.rada.gov.ua/laws/show/78-IX\#Text [in Ukrainian].

Vogel, T., Schmidt, A., Lemm, A., \& Osterle, H. (2008). Service and Document Based Interoperability for European eCustoms Solutions. Journal of Theoretical and Applied Electronic Commerce Research, 3, 3, 17-37. DOI: $10.4067 / \mathrm{S} 0718-18762008000200003$

Wilmott, P. (2007). A Review of The European Commission's Plans for An Electronic Customs Environment. World Customs Journal, 1, 1, 11-17. https://cutt.ly/imKvWGx

WTO Committee on Trade Facilitation. (2018, May 2). European Union Customs Transit including arrangements with neighbouring countries under the Common Transit Convention. https://www.wto.org/english/tratop_e/tradfa_e/ comm_e/meet26june_eu_nonpaper_2_e.pdf

\footnotetext{
Кріль Р. Спільна транзитна процедура та впровадження NCTS: приклад Украӥни. - Стаття.

У статті проаналізовано політику СС щодо розширення процедури спільного транзиту та нової комп'ютеризованої транзитної системи (NCTS) на асоційовані країни з урахуванням прикладу України. Значний обсяг дій та допомоги $\mathrm{CC}$ щодо впровадження NCTS здійснюється в рамках Східної політики сусідства. Це має важливе значення для наближення митного законодавства, збільшення потенціалу та модернізації митних органів сусідніх
} 
з СС держав. Однак вплив від впровадження NCTS виходить далеко за рамки звичайної організації процедури транзиту. Результатом цього може бути запровадження базових принципів адміністративного законодавства ЄС та найкращих практик адміністрування у повсякденну діяльність національних митних органів. Українська митниця має сприятливі стартові умови; наразі національні митні органи та суб'єкти ЗЕД мають досвід використання митних IT-рішень. Однак перехід до нової процедури транзиту може зіткнутися 3 певними проблемами через непропорційно жорсткі критерії надання дозволів на транзитні спрощення, встановлені національним законодавством, які перевищують відповідні вимоги законодавства ЄС. Такі обмеження спричиняють низьку популярність нових митних процедур, гармонізованих із законодавством ЄС. Крім того, у деяких випадках наближення до митного законодавства $Є С$ призводить до припинення існуючих спрощень митних процедур, що ставить питання щодо спотвореного виконання відповідних зобов’язань та несприйняття основних принципів доброго адміністрування, які просуваються СС.

Ключові слова: процедура спільного транзиту, NCTS, транзитні спрощення, Угода про асоціацію, європеїзація, добре урядування, митниця, Європейський Союз, Україна.

\section{Криль Р. Общая процедура транзита и реализация NCTS: пример Украины. - Статья.}

В статье проанализирована политика ЕC по расширению процедуры общего транзита и новой компьютеризированной транзитной системы (NCTS) на ассоциированные страны с учетом примера Украины. Значительный объем действий и помощи ЕC по внедрению NCTS предоставляется в рамках Восточной политики соседства. Это имеет важное значение для сближения таможенного законодательства, увеличения потенциала и модернизации таможенных органов соседних с ЕС государств. Однако влияние внедрения NCTS выходит далеко за рамки обычной организации процедуры транзита. Его результатом может быть внедрение базовых принципов административного законодательства ЕС и лучших практик администрирования в повседневную деятельность национальных таможенных органов. Украинская таможня имеет благоприятные стартовые условия; сегодня национальные таможенные органы и субъекты ВЭД имеют опыт использования таможенных IT-решений. Однако переход к новой процедуре транзита может столкнуться с определенными проблемами из-за непропорционально жестких критериев предоставления разрешений на транзитные упрощения, установленные национальным законодательством, которые превышают соответствующие требования законодательства ЕС. Такие ограничения 
вызывают низкую популярность новых таможенных процедур, гармонизированных с законодательством ЕС. Кроме того, в некоторых случаях сближение с таможенным законодательством ЕС приводит к прекращению существующих упрощений таможенных процедур, что ставит вопрос об искаженном выполнении соответствующих обязательств и неприятии основных принципов хорошего администрирования, которые продвигаются ЕС.

Ключевые слова: процедура общего транзита, NCTS, транзитные упрощения, Соглашение об ассоциации, европеизация, хорошее управление, таможня, Европейский Союз, Украина. 